\title{
Az állam szerepe a feltörekvő multinacionális vállalatok terjeszkedésében. Kína és Brazília esete ${ }^{1}$ The Role of the State in the Global Expansion of Emerging- Markets Multinationals. The Cases of China and Brazil
}

\section{Ricz Judit és Szunomár Ágnes \\ https://doi.org/10.47707/Kulugyi_Szemle.2020.4.06}

\begin{abstract}
Összefoglaló: A feltörekvő országok multinacionális vállalatainak (FMNV-k) globális terjeszkedésében központi szerepet játszik a saját kormányzatuk. Az egyik legkézenfekvőbb példa Kína és a kínai cégeknek a globális piacra lépése, ugyanakkor mind az új államkapitalizmus, mind az FMNV-k állami támogatása túlmutat a kínai eseten. A Globális Dél számos országában megfigyelhetünk hasonló tendenciákat és kezdeményezéseket - többek között Brazíliában is. A brazil modell sok tekintetben alapvetően különbözik a kínaitól, ugyanakkor a "nemzeti bajnok" vállalatok külföldi piacra lépését ott is kiterjedt kormányzati eszköztár támogatja, így ebből a szempontból a brazil és a kínai eset összehasonlítása releváns és indokolt. Az írás célja a főbb hasonlóságok és különbözőségek feltárása; az esettanulmányok elemzéseire támaszkodva pedig visszacsatolunk a legújabb elméletekre, és következtetéseket fogalmazunk meg, amelyek akár más, hasonló adottságokkal vagy fejlesztési stratégiákkal rendelkező feltörekvő országok számára is hasznosak lehetnek.
\end{abstract}

Kulcsszavak: Kína, Brazília, állami támogatás, feltörekvő országok multinacionális vállalatai (FMNV)

Abstract: One of the decisive features of the recent rise of emerging-market multinational enterprises (EMNES) is the role of home country governments and their policies. The most obvious example is provided by China, by the entry of Chinese companies into the global markets; however, both the newly emerging version of state capitalism as well as the state support for EMNEs go beyond the Chinese case. Similar trends and strategies can be observed in numerous countries of the Global South, including - among others - Brazil. The Brazilian model deviates in several aspects from the Chinese variant, while the global expansion of national champions and other companies were also extensively supported by public policies, thus in this respect the comparative analysis of the Brazilian and the Chinese cases is relevant and justifiable. By comparing the two cases, the paper aims to explore similarities and differences with providing

1 E kutatás a Nemzeti Kutatási, Fejlesztési és Innovációs Hivatal (NKFIH) által támogatott „A fejlesztő államoktól az új protekcionizmusig: a fejlesztésorientált beavatkozások átalakuló repertoárja a formálódó új világrendben" (FK_124573), valamint az „Európán kívüli feltörekvő piacok multinacionális vállalatai Kelet-Közép-Európában” (K_120053) címú projekt támogatásával, továbbá a Bolyai János Kutatási Ösztöndíj keretében és az Új Nemzeti Kiválósági Program (ÚNKP-19-4-BCE-12) támogatásával készült. Az anyag a szerzők egy korábban megjelent tanulmányának átdolgozott és kibővített változata. Lásd: Ricz és Szunomár, 2020, 159-171. 0. 


\section{Külügyi Szemle}

feedback to most recent theories and to formulate insights and lessons for other emerging economies with similar endowments or development strategies.

Keywords: China, Brazil, state support, emerging-market multinational enterprises (EMNES)

\section{Bevezető}

Az állam aktív, fejlesztésorientált beavatkozásainak kiterjedt történelmi hagyományai vannak. A napjainkban megfigyelhető reneszánszuk az államkapitalista kísérletek harmadik hullámának tekinthető (Nölke, 2014; Kurlantzick, 2016), ugyanakkor a korábbiaktól jelentősen eltérő eszköztárral, azoknál változatosabb megjelenési formákkal rendelkezik. Bár a növekvő állami szerepvállalás a 2008-2009-es válság után globális tendenciává vált, az állam vezérelte kapitalizmus e legújabb verziója mégis elsősorban a nagy feltörekvő gazdaságokra jellemző, és szorosan összekapcsolódik a sikeres feltörekvő multinacionális vállalatok (FMNV-k) terjeszkedésével.

Az FMNV-k globális terjeszkedési stratégiája nem tér el teljes egészében a fejlett multinacionális vállalatok (MNV-k) gyakorlatától, mégis jelentős különbségek tapasztalhatók mind a motivációk, mind a múködési gyakorlat tekintetében. Az egyik legfontosabb ilyen tényező a hazai kormányzat szerepe a sikeres nemzetközi terjeszkedésben. Sokszor éppen azok az ún. "nemzeti bajnok” vállalatok sikeresek a nemzetközi piacokon is, amelyek jelentős hazai hátszéllel bírnak. Ezek lehetnek részben vagy teljesen állami tulajdonban álló vállalatok, de akár olyan magáncégek is, amelyek a (sok esetben közvetlen vagy közvetett pénzügyi előnyöket is biztosító) hazai szektorális vagy külgazdasági stratégiák és politikák révén jelentős állami támogatásokhoz jutnak.

Az egyik legkézenfekvőbb példa Kína és a kínai vállalatoknak a globális piacra lépése. A kínai kiáramló tőkebefektetések hátterében ugyanis számos pekingi kormányzati ösztönző található, rendkívül kiterjedt eszköztárral - az általános nemzeti stratégiáktól a kidolgozott iparági irányelveken és ágazati terveken keresztül az ugyancsak átfogóbb politikai kerettervekig, mint például a go global stratégia vagy legújabban az Övezet és Út Kezdeményezés (Belt and Road Initiative, BRI).

A jelen írásban ugyanakkor amellett érvelünk, hogy mind az államkapitalizmus harmadik hulláma, mind a feltörekvő multinacionális vállalatok állami támogatása túlmutat a kínai eseten. A Globális Dél számos országában (Délkelet-Ázsiától Dél-Afrikán át Latin-Amerikáig) hasonló tendenciákat és kezdeményezéseket figyelhetünk meg. DélAmerika legnagyobb országa, Brazília az ezredforduló után az államkapitalizmus új laboratóriumává vált. A brazil modell sok tekintetben alapvetően különbözik a kínaitól, ugyanakkor a nemzeti bajnok vállalatok külföldi piacra lépését ott is kiterjedt kormányzati eszköztár támogatta, így ebből a szempontból a brazil és a kínai eset összehasonlítása releváns és indokolt lehet. A két modell összevetésével a jelen írás az esetleges 
hasonlóságok és különbözőségek feltárását célozza, azzal a nem titkolt szándékkal, hogy az esettanulmányok elemzései, eredményei alapján visszacsatoljon a legújabb elméletekre is - mind a feltörekvő multinacionális vállalatok nemzetközi piacra lépési stratégiáit illetően, mind az államkapitalizmus legújabb generációjának a variánsai tükrében. Végül, de nem utolsósorban, a két eset összehasonlítása akár más hasonló adottságokkal vagy fejlesztési stratégiákkal rendelkező feltörekvő országok számára is hasznos lehet.

Az írás öt részből áll: a bevezető után röviden bemutatjuk a feltörekvő multinacionális vállalatok növekvő gyakorlati és elméleti jelentőségét. A harmadik és negyedik fejezet a kínai és a brazil esettanulmányt tartalmazza, hasonló struktúrában és azonos súlypontokkal. A tanulmányt végül rövid összehasonlító elemzéssel és az általánosítható következtetések megfogalmazásával zárjuk.

\section{A feltörekvő multinacionális vállalatok globális terjeszkedése: a fókuszban Kína és Brazília}

Bár a feltörekvő országok multinacionális vállalatainak a tőkebefektetései a nyolcvanas-kilencvenes évek óta jelen vannak a fejlett világban, az elmúlt két évtizedben onnan érkezett külföldi működőtőke-befektetés (foreign direct investment, FDI) nagyságrendjének a növekedése új korszakot nyitott a nemzetközi tőkebefektetések területén. Az egyik első ilyen mozzanat a kínai go global stratégia meghirdetése és a kínai vállalatok globális jelenlétének a növekedése volt. A "feltörekvő multik" által az utóbbi évtizedekben végrehajtott vállalatfelvásárlások, illetve zöldmezős beruházások új trendet mutatnak, és új típusú, a korábbiaktól eltérő gyökerú és hátterú vállalatok válnak jelentős globális szereplőkké.

A FMNV-k felemelkedéséért elsősorban Ázsia - korábban Dél-Korea, Tajvan és Szingapúr, ma sokkal inkább Kína és India - a "felelős", de napjainkban e folyamat egyre több régióra terjed ki, s megfigyelhető például a latin-amerikai (s kiemelten a brazil) cégek esetében is, így jó alapot jelent a „klasszikus” kínai esettel való összehasonlításhoz. A globális tendenciákhoz hasonlóan, az általunk vizsgált két országban, Kínában és Brazíliában is a 2000-es évek elején indult lendületes növekedésnek az FDI. A két ország sokáig fej-fej mellett haladt mind a tőkeállomány, mind a tőkeáramlás éves mennyisége tekintetében (enyhe brazil fölénnyel), majd 2007-től a kínai kiáramló tőke jelentős növekedésnek indult, miközben a brazil a korábbi szinten maradt, s csak enyhe - hol pozitív, hol negatív irányú - változás jellemezte (1. ábra). 


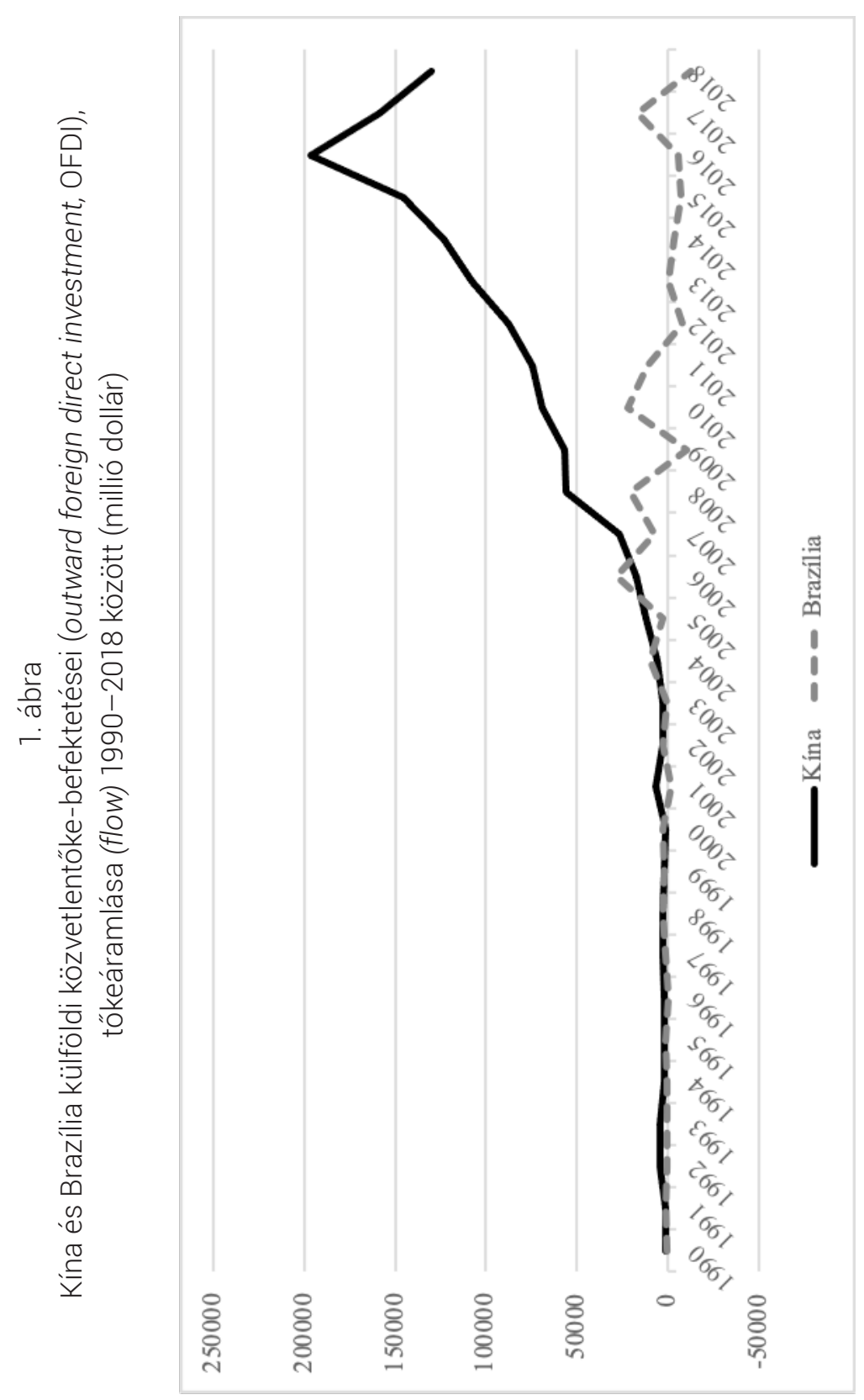

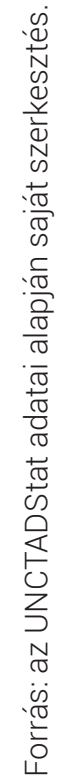


Az 1. ábrán jól látható, hogy a globális gazdasági és pénzügyi válság hatalmas lendületet adott a kínai OFDI-nek, miközben a brazil FDI növekedése meglehetősen szerény maradt, sőt 2009-ben tőkekivonást is végre kellett hajtani. Az utóbbi években a brazil tőkeáramlás viszonylag volatilisnek mondható, s sokszor csúszik negatív tartományba, azaz vannak olyan periódusok, amikor a tőkekivonás mértéke meghaladja a befektetésekét. Mindez a brazil tőkeállomány szintjének enyhe csökkenésével jár, s összességében szerény stagnálást jelent. Kína viszont 2016-ig folyamatosan és stabilan növelni tudta a kiáramló tőke mennyiségét, amely akkor a tőkekiviteli szabályozás szigorítása miatt valamelyest visszaesett ugyan, de a tőkeállomány továbbra is növekedett, s csupán annak mértéke mérséklődött kissé.

Az FDI motivációjára irányuló korábbi elméletek² elsősorban makrogazdasági, illetve strukturális tényezőkkel magyarázták a multinacionális vállalatok döntéseit, napjainkban azonban a hagyományos gazdasági tényezők figyelembevétele már egyre kevésbé elégséges a magyarázathoz. Az elmúlt évtizedben a hagyományos (cégspecifikus) stratégiai motivációk mellett mindinkább előtérbe került az intézményi tényezők vizsgálata is. Az alábbiakban ez utóbbiak egy nagyon tipikus szeletére fókuszálunk: a küldő ország mindenkori kormánya által az FMNV-knek nyújtott aktív támogatásra, amely közvetett vagy közvetlen módon segíti elő a külső piacok meghódítását. Sauvant, Economu, Gal, Lim és Wilinski (2014) az alábbi eszközöket emeli ki a hazai kormányzat OFDI-ösztönző lehetőségeinek a tipizálása során: a hazai intézményi és szabályozási keretek meghatározása; a külpiacra lépés segítése információs és egyéb támogató szolgáltatásokkal; pénzügyi támogatások nyújtása (beleértve az adókedvezményeket is); beruházásvédelmi (biztosítási) és egyéb kétoldalú egyezmények kötése.

A szakirodalomban a hazai kormányzat szerepének elemzésével is egyre több szerző foglalkozik, ők azonban jellemzően egyes egyedi esetek, bizonyos országok tapasztalatainak a feltárására szorítkoznak. Legjobb tudomásunk szerint elhanyagolható azon elemzések száma, amelyek szisztematikusan elemeznék a feltörekvő országok stratégiáinak a hasonlóságait és az eltéréseit, valamint azoknak a megvalósuló külföldi közvetlen tőkebefektetésekre, valamint - tágabban véve - az adott ország fejlődési pályájára és kilátásaira gyakorolt hatásait. A kínai és a brazil OFDI-stratégiák összehasonlító elemzése által a jelen írás az említett hiányosság pótlására irányuló első kísérletek egyike lehet.

2 Az elméleti háttér részletesebb kifejtése: Ricz és Szunomár, 2020, 159-171. o. 


\section{Külügyi Szemle}

\section{A kínai multinacionális vállalatok nemzetközi terjeszkedésének föbb hajtóerői}

A kínai FDI folyamatosan növekedett az elmúlt évtizedekben, azonban 2010 után e folyamat jelentősen felgyorsult. 2012-ben az Amerikai Egyesült Államok és Japán mögött 84 milliárd dolláros tőkekiáramlással Kína lett a világ harmadik legnagyobb befektetője - míg egy évvel korábban csupán a hatodik helyen végzett. Az akkor elért pozícióját a későbbiekben is meg tudta őrizni: 2016-ban több mint 190 milliárd, 2017ben közel 160 milliárd, 2018-ban pedig 130 milliárd dollárnyi tóke áramlott ki Kínából. Az utóbbi révén Kína már a második legjelentősebb tőkekihelyező ország lett Japán után (csupán 13 milliárd dollárral lemaradva); a felhalmozott vállalati jövedelmek repatriálása miatt ugyanis a korábbi „első helyezett”, az Egyesült Államok tőkeáramlása 2018-ban negatívba fordult. A kínai külföldi közvetlentőke-állomány 2019 végén már több mint 2000 milliárd dollár volt az OECD adatai szerint.

Számos tényező támogatta és támogatja mai is a kínai vállalatok FDI-növekedését, köztük a kínai kormányzatnak a globálisan is versenyképes kínai vállalatok iránti elvárása, illetve annak a felismerése, hogy a külföldi tôkebefektetések több csatornán keresztül is hozzájárulhatnak az ország fejlődéséhez. Erre alkalmasak például:

- a természeti erőforrások feltárására irányuló beruházások;

- a hazai technológiák, termékek, felszerelések és munkaerô exportja;

- a technológiai fejlesztések;

- a versenyképességnek a kínai márkák népszerúsítésén, valamint az értékesítés, a kínálat és a termelés globális hálózatának a felépítésén alapuló növelése (Sauvant és Chen, 2014, 141-142. 0.; Luo, Xue és Han, 2010, 76. O.; Caseiro és Masiero, 2014, 248. o.).

\section{A kinai FDI fejlődésének történeti áttekintése és főbb jellemzői}

Kínában a nyitási politika reformjaival párhuzamosan a kormány már az 1970-es évek végétôl ösztönözte a külföldi befektetéseket, hogy azzal is elősegítse az országnak a globális gazdaságba történő integrálását. Igaz, akkoriban még csupán az állami tulajdonú vállalatok számára volt nyitott ez a lehetőség. Az első években megvalósult beruházások mennyiségi értelmében még nem voltak jelentősek, és jellemzően a szomszédos országokban, főleg Hongkongban koncentrálódtak. A külföldi befektetésekre vonatkozó rendeleteket 1985 után liberalizálták, és már a vállalkozások szélesebb köre - például a magánvállalkozások - számára is engedélyezték, hogy külföldön fektessenek be. Az igazi lökést azonban nem a rendelet lazítása, hanem Teng Hsziao-ping híres, 1992-es dél-kínai útja adta meg. Azt követően ugyanis korábban soha nem 
tapasztalt mértékben növekedtek a tengerentúli beruházások is: a kínai vállalatok szinte az egész világon létrehoztak részlegeket, amely során elsősorban a természeti erőforrásokra koncentráltak.

Bár az 1990-es évek folyamatai már sejttették, hogy Kína nem csupán tőkebefogadó, de tőkekihelyező országként is jelentős szereplő lehet, az új évezred a korábbiaknál is jelentősebb állami/kormányzati elhatározást és ösztönzőket hozott. A kínai kormány 2000-ben, még mielőtt az ország csatlakozott a Kereskedelmi Világszervezethez (World Trade Organisation, WTO), megkezdte a go global politikát, amelynek célja a hazai vállalatok globális versenyképességének az elősegítése volt. Olyan új rendelkezéseket, politikákat vezettek be, amelyek a mai napig arra ösztönzik a cégeket, hogy a különféle iparágak terén - elsősorban a kereskedelemmel kapcsolatosan - tengerentúli tevékenységekben vegyenek részt. Ez a politikai váltás része volt a kínai gazdaság 2000-es évek elejét jellemző reformjának és liberalizációjának, és tükrözte az akkori kínai kormány azon vágyát is, hogy nemzetközileg versenyképes és jól ismert vállalatokat és márkákat hozzon létre.

A kínai FDI az említett politikai váltás, valamint a globális gazdasági és pénzügyi válság következtében az elmúlt évtizedben, különösen 2008 után, folyamatosan nőtt: a válság ugyanis számos olyan új lehetőséget is teremtett a kínai vállalatok számára, amelyek révén növelni tudták a részesedésüket a világgazdaságban, hiszen akkoriban igencsak megnőtt a nehéz pénzügyi helyzetben lévő vállalkozások száma, különösen a fejlett világban. ${ }^{3}$

Clegg és Voss (2012) szerint az Európai Unióba irányuló kínai FDI a 2003. évi 0,4 milliárdról 6,3 milliárd dollárra nőtt 2009-re, az éves növekedési üteme 57 százalék volt, azaz jóval meghaladta a kínai FDI globális növekedési ütemét. 2016-ban a kínai vállalatok már 35 milliárd eurót fektettek be az EU-ban, ami 77 százalékkal magasabb, mint az előző évi adat volt (Hanemann és Huotari, 2017, 4. o.). Miközben az erőforrásokban gazdag régiók továbbra is fontosak a kínai vállalatok számára, a 2008-as pénzügyi és gazdasági válság óta a vállalatfelvásárlások iránt is nő az érdeklődés - főleg egy-egy fejlett világbéli, például európai cég esetén. Az érdeklődés fő oka az, hogy a megvásárolt európai vállalatok révén a kínaiak fontos technológiákhoz, sikeres márkákhoz és elosztási csatornákhoz, menedzseri tudáshoz férhetnek hozzá (Clegg és Voss, 2012, 16-19. о.).

3 Míg a fejlett világból származó FDI több országban is csökkent a válság miatt, a kínai külföldi befektetések a korábbiaknál is nagyobb mértékben növekedtek: míg az előbbieké csupán 32, addig Kínáé 189 százalékkal bővült 2007 és 2011 között (UNCTAD 2013). 


\section{Külügyi Szemle}

2. ábra

A kínai FDI földrajzi eloszlása, 2017 (százalék)

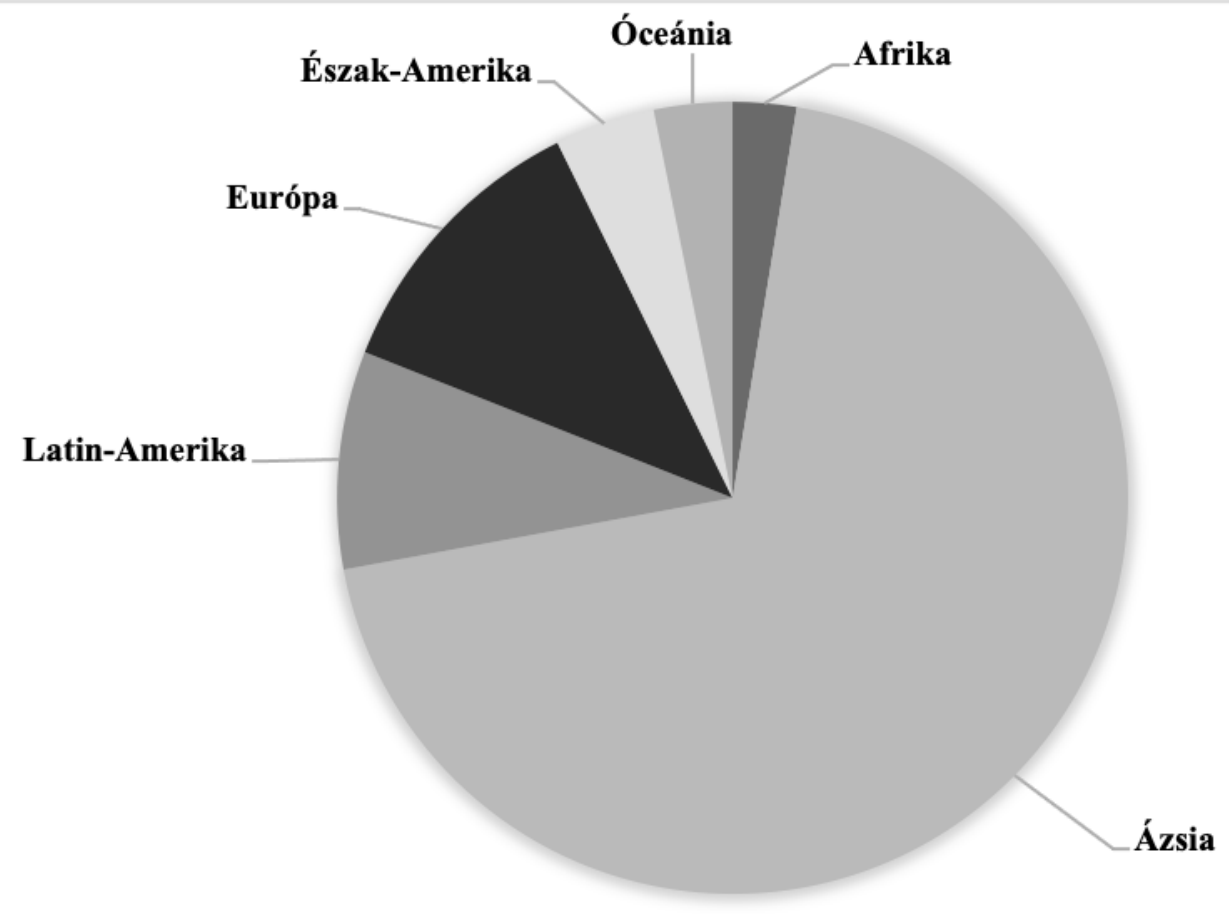

Forrás: a MOFCOM és a Kínai Nemzeti Statisztikai Hivatal adatai alapján.

Noha az említett növekedés mindenképpen jelentős, a kínai statisztikák szerint az Európába vagy az Egyesült Államokba irányuló FDI csupán töredékét jelenti az összes külföldi közvetlentőke-befektetésüknek, míg például az Ázsiába irányuló sokkal nagyobb. A kínai OFDI tényleges végső rendeltetési helyének vizsgálata során azonban Wang (2013) megállapította, hogy azok közül az úgynevezett körbejáró (round tripping) beruházások eredményeként a fejlett országok valójában többet fogadnak, mint a fejlődő gazdaságok: projektszintú adatelemzése szerint a kínai külföldi közvetlen befektetések 60 százaléka olyan fejlett gazdaságokba áramlott, mint Ausztrália, Hongkong, az Egyesült Államok, Németország és Kanada. A kínai vállalatok belépési módját illetően is változás volt megfigyelhető az elmúlt időszakban: a zöldmezős beruházások továbbra is fontosak, de erősödik a tengerentúli fúziók és felvásárlások (M\&A), valamint a vegyesvállalati projektek tendenciája is.

Az eddig ismertetetteken kívül szektorális szinten is kimutatható egyfajta diverzifikáció, amely ugyancsak az utóbbi időszak jellemzője. A fejlett gazdaságok kapcsán a kínai befektetéseket kevésbé motiválja a természeti erőforrások keresése vagy a kereskedelemmel kapcsolatos előnyök szerzése, sokkal inkább a piac-, hatékonyság- és 
stratégiaieszköz-keresési célok vezérlik. E befektetésekre az is jellemző, hogy bár az FDI-ügyletek értékét tekintve az állami tulajdonú vállalatok a jelentősebb szereplők, viszont a magántulajdonban lévők szám szerint több projektet mondhatnak magukénak (Rosen és Hanemann, 2013, 71. o.).

\section{A kínai FDI motivációi: a "lökést adó" tényezôk és az állami politikák}

A külföldi közvetlentőke-befektetések motivációit hagyományosan két csoportra bonthatjuk: az úgynevezett lökést adó (push) és a húzó (pull) tényezőkre; ezáltal megkülönböztetjük egymástól azokat, amelyek a székhely szerinti ország oldaláról elősegítik, bátorítják, támogatják a beruházásokat, illetve amelyek vonzó befektetési célponttá teszik/tehetik a fogadó országot egy adott vállalat számára. E cikkben a székhely szerinti ország által meghatározott faktorokra, a lökést adó tényezőkre összpontosítunk, azon belül is külön figyelmet fordítva az adott kormányzatának az FMNV-k nemzetközivé válásának előmozdításában játszott szerepére.

A fejlődő országokban működő vállalatok nemzetközivé válását elősegítő tényezőknek számos típusa létezik. Ilyenek az intézményi és a strukturális tényezőket. Az utóbbiak - mint a bruttó hazai termék (GDP), az exportorientáció vagy az árfolyam volatilitása - elsősorban a székhely szerinti ország gazdaságához és piacához kapcsolódnak. Az előbbiek pedig összefügghetnek például a székhely szerinti és a fogadó ország közötti kulturális közelséggel/távolsággal, a kormányzati politikával (köztük a konkrét ösztönzőkkel, adókkal) vagy a különböző intézményi szereplőkkel és azok kölcsönhatásával (Voss, Buckley és Cross, 2009; Schüler-Zhou, Schüller és Brod, 2012; Luo et al., 2010).

A már említett go global stratégia szerint a kínai vállalatoknak globálisan versenyképessé kell válniuk, ugyanakkor az "indító” ok más és más lehet. A leggyakrabban hangsúlyozott motiváció a természeti erőforrások, elsősorban az energia és a nyersanyag iránti igény, amelyekre Kína további fejlődésének biztosítása érdekében van szükség (erőforrás-kereső motiváció). Emellett természetesen megjelenik a piac bővítését vagy a nemzetközi szintű diverzifıkációt célzó beruházás (piackereső motiváció) is, de a szállítás és a biztosítás szintén fontos befolyásoló tényező (Davies, 2013, 736. o.). Annak ellenére, hogy a kínai munkaerő-kínálat továbbra is jelentős, számos esetben helyezik át a kínai vállalatok a termelést olyan - például délkelet-ázsiai - országokba, ahol alacsonyabb a munkaerőköltség (hatékonyságnövelő motiváció). Az utóbbi években megfigyelhető továbbá, hogy kínai multinacionális vállalatok közismert globális márkákat vagy disztribúciós csatornákat, vezetési készségeket keresnek a vállalatfelvásárlásaik révén, míg a külföldön történő befektetés egy újabb fontos oka lehet a technológiaszerzés is (stratégiaieszköz-kereső motiváció). Scissors $(2014,4$. o.) arra mutatott rá, hogy 


\section{Külügyi Szemle}

a hazainál tisztább tulajdonjogi viszonyok szintén nagyon vonzóak a kínai befektetők számára, míg Morrison (2013) szintén egy megkerülhetetlen tényezőt, Kína devizatartalék-felhalmozását emelte ki: a viszonylag biztonságos, de alacsony hozamú eszközök, például az amerikai kincstárjegyek mellett a kínai kormány diverzifikálni akar, és nagyobb hozamot keres.

Kezdetben csak az állami tulajdonú kínai vállalatok fektettek be külföldön, közülük is elsősorban azok, amelyek az ország természetierőforrás-hiányát pótló beszerzésben voltak érdekeltek. A magántulajdonban álló vállalatok külföldi közvetlentőke-befektetéseinek támogatásáról 2006 februárjában született kormányzati döntés. Az FDIprojektek jóváhagyási folyamatán és a deviza- és a kedvezményes kölcsönökhöz való hozzáférés révén azonban a kormány továbbra is közvetlen befolyást gyakorolhat a külső befektetések növekedésére és irányára. A Kínai Népköztársaság Kereskedelmi Minisztériuma (MOFCOM) például jó szemmel nézi, ha a vállalatok olyan országokban fektetik be a tókéjüket, amelyek

1. szoros kapcsolatban állnak Kínával;

2. gazdasága és kínai gazdaság kölcsönösen jól kiegészíti egymást;

3. Kína fontos kereskedelmi partnerei;

4. befektetési és adóügyi megállapodásokat írtak alá Kínával; és

5. a globális gazdaság valamelyik fontos régiójának a részei (MOFCOM, 2004).

A kínai vállalati befektetések kívánt földrajzi és ágazati irányát az "Iparági katalógus a külföldi befektetések irányításához" címú dokumentum szabályozza, amely az egyes iparágakat az ösztönzöttek, a korlátozottak vagy a tiltottak közé sorolja. A gyártás tekintetében a legnépszerúbbnek általában az elektromos gépek és a fogyasztói elektronika, míg a szolgáltatások esetében a kereskedelem és az értékesítés számít. A magasabb technológiai fejlettségű EU-tagországokban, pl. Franciaországban, Németországban és Svédországban, valamint az Egyesült Királyságban történő K+F-beruházásokat a kormány kiemelten támogatja. Az IT-szolgáltatásokba való beruházást pedig elsősorban az „úi”" EU-tagállamok esetén ajánlja.

Kína sok szempontból valóban élen jár a nagyvállalatok állami ellenőrzésében, azonban az államkapitalizmus és a fejlesztó államok régebbi változataival ellentétben ott ma nem alkalmazzák sem a klasszikus, felülről lefelé történő irányítást, és nem létezik egy olyan családi/központi irányítású vállalati modell sem, mint például a dél-koreai chaebol vagy a japán keiretsu rendszer. A kínai állami ellenőrzés jellemzőire vonatkozóan számos nézetet különböztethetünk meg. Az egyik ilyen feltételezés Nölke, Ten Brink, Claar és May (2015) államkapitalizmus-modellje, amelyben az állami-üzleti koalíciók tagjai közötti lojalitás és bizalom mechanizmusai jellemzően informális személyes kapcsolatokon alapulnak. Witt és Redding (2013) a kínait inkább egy olyan rendszernek tekinti, 
amely a ragadozó elemeket és a személyes kapcsolatokat kombinálja, miközben maguk a kínaiak ma is a belső és külső stabilitást is biztosító, erős, de hatékony kormányzat előnyeit hangsúlyozzák.

Mi magunk azt az elképzelést osztjuk, amely szerint Kína önmagában is egy sajátos modellt alkot, amelyet a szocializmusról a kapitalizmusra való tartós - sőt, talán soha véget nem érő - átmenet jellemez. A jelenlegi kínai helyzet nem írható le csupán az állami versus magántulajdonú vállalati distinkcióval: a pénznyelő, rossz hiteleket felhalmozó és kevéssé hatékonyan múködő állami mamutok és a tisztán magántulajdonú vállalkozások mellett egyszerre vannak jelen az olyan jövedelem- és versenyorientált állami ellenőrzésú vállalatok, mint a China Mobile, miközben számos, állami támogatással múködő magánvállalat és állami-magán hibrid is létezik - ilyen például a Huawei, a Lenovo vagy a Geely -, amelyek a kínai piacon és világszerte is sikerrel múködnek (Nölke et al., 2015). Manapság az ilyen nem állami tulajdonú - de különböző állami intézkedések révén támogatott - vállalatokat az állami vezetők "nemzeti bajnokoknak" tekintik (Naughton, 2007; Ten Brink, 2013). Néhány kivételtől eltekintve - ilyen például az informatikai szektor, amely már mélyen integrálódott a globális termelési hálózatokba a legtöbb iparágban a nemzeti (állami ellenőrzésú, hibrid és magán-) tőke dominál, nem pedig a külföldi multinacionális cégek (Nölke et al., 2015).

\section{A brazil multinacionális vállalatok globális piacra lépése}

Brazília gazdasági felemelkedésének egyik szembetűnő jele volt az ezredfordulót követően a brazil vállalatok globális terjeszkedése. Történelmileg azok ugyanis jellemzően a hazai (és esetleg a regionális) piacokra fókuszáltak. A természeti erőforrásokban gazdag ország és a nagy belső piaca ezt lehetővé tette, de emellett a hoszszú évtizedeken át folytatott importhelyettesító iparosítás is hozzájárult ahhoz, hogy Brazília az 1970-es évek végére a világ egyik legzártabb gazdaságává vált. Mindezek következtében a brazil vállalatok kevésbé érezték fontosnak a külpiaci terjeszkedést, és többnyire versenyképességi korlátokkal is küzdöttek. Az 1990-es évek közepén, a gazdasági stabilizáció és piacorientált reformok következtében Brazília a nemzetközi tőkeáramlások fontos célországává (befogadójává) vált. Az ezredfordulót követően azonban már - más feltörekvő országokhoz hasonlóan - jelentős külföldi befektetőként is megjelent a világpiacon.

2006-ban Brazíliában a kiáramló külföldi befektetések meghaladták a beáramlókat. Ez a korábban soha nem tapasztalt jelenség jól mutatja egy olyan ország nemzetköziesedési folyamatát, amely kifejezetten a globális szereplőként betöltött pozíciójának a megszilárdítását célozta - Id. Luiz Inácio Lula da Silva (a továbbiakban: Lula) elnök külpolitikai és -gazdasági ambícióit. 2006 azonban csupán egy kivételes év 


\section{Külügyi Szemle}

maradt, sőt az akkori eredmény könnyen magyarázható egyetlen tranzakcióval: a brazil ércbányászati óriás, a Vale kb. 17 milliárd dollárért felvásárolta a kanadai Inco céget (Resende, Almeida és Ramsey, 2010, 99. o.), és ez maga az éves kiáramló tőke több mint 60 százalékát tette ki. A mai napig előfordul, hogy a kiáramló brazil tőkemennyiséget évente egy-két tranzakció jelentősen befolyásolja. Ennek hátterében a kiáramló tőke viszonylag alacsony mennyisége és évenkénti nagy ingadozása áll.

\section{A brazil cégek nemzetközi piacra lépésének történeti áttekintése és föbb jellemzői}

Bár a jelen tanulmány a 2000-es évekre helyezi a hangsúlyt, kiemelendő, hogy a brazil vállalatok nemzetközi piacra lépése egy hosszú történelmi folyamat eredménye, amely az 1960-as és 1970-es évekre nyúlik vissza. Kezdetben elsősorban a földrajzi és kulturális közelség által meghatározott ún. „természetes piacokon” (a latin-amerikai, valamint a spanyol vagy portugál nyelvű európai és afrikai országokban) terjeszkedtek. Az 1990-es évek piacorientált reformjaival párhuzamosan a hazai piacon megjelent erős verseny, a külföldi cégek brazíliai befektetései hatására kialakult "kompetitív sokk" (Casanova és Kassum, 2014, 84. o.) kényszerítette őket a működésük átszervezésére, többek között a külpiaci tevékenységük újragondolására.

A brazil vállalatok legsikeresebb és legaktívabb globális terjeszkedése 2003 és 2008 között zajlott. A magas nyersanyagárak és a felfutó kínai kereslet hatására elsősorban a nyersanyag-kitermelésen alapuló cégek, például a Petrobras és a Vale, nagy nemzetközi felvásárlásokba kezdtek a közeli országokban és más feltörekvő régiókban (főleg Afrikában). A külpiaci húzóerők mellett a kedvező hazai gazdasági folyamatok tolóerőként hatottak: otthon jól ment az üzlet, és egyre több cég kezdett nemzetközi terjeszkedésbe, ráadásul a külgazdasági és -politikai célok között egyértelmúen megjelent a cégek nemzetközi terjeszkedésének a támogatása, valamint egyes gazdaságpolitikai intézkedések is a nemzetközi expanziónak kedveztek.

2008-tól - a fejlett államokból kiindult globális pénzügyi és gazdasági válság következtében - a feltörekvők lettek a nemzetközi tőkeáramlások legfőbb célországai és tágabban véve a globális gazdaság növekedési motorjai. A főbb brazil vállalatok is oda, sőt esetenként ismét a hazai piac felé helyezték át a gazdasági tevékenységük fő fókuszát. Azonban 2016 után a sokrétű brazil válság különböző dimenzióinak a hatásai összeadódtak, és a kiáramló tőke mennyisége is mélypontra jutott, hiszen a brazil multinacionális vállalatok már korábban hazatelepítették a kihelyezett tókéjük egy részét (elsősorban vállalaton belüli tranzakciók révén). Míg az elemzők többsége 2012-ben, sőt még 2014-ben is a brazil vállalatoknak a gazdasági instabilitással és volatilitással szembeni ellenálló képességéről írt, addig 2017-ben már a válság alatti tőkekivonásról szóltak a híradások (Sheng és Carrera, 2017). 
A 2015-re kibontakozódott brazil válság komplexitása 2016-ra még inkább nyilvánvalóvá vált (Ricz és Nagy, 2016): a súlyos gazdasági visszaesés ${ }^{4}$ mellett a Petrobrast és más brazil nagyvállalatokat övező hatalmas és tovagyűrűző korrupciós botrány, valamint az alkotmányos vádeljárás (impeachment) után hatalomra került új politikai vezetés és az általa végrehajtott gazdaságpolitikai fordulat alapvetően megváltoztatta a peremfeltételeket, s jelentősen befolyásolta a legtöbb brazil vállalat nemzetközi expanziós stratégiáját és annak végrehajtását. A korrupciós botrányban érintett cégek többsége a külföldi leányvállalatai eladását, illetve a beruházási terveik felülvizsgálatát, csökkentését irányozta elő annak érdekében, hogy ki tudják fizetni a kiszabott bírságokat. Erre a legszembetűnőbb példát a Petrobras szolgáltatta, amely 2019-ig legalább 25 százalékkal (32 milliárd dollárnak megfelelő összeggel) csökkentette a beruházásait.

A legnagyobb brazil cégek kiemelkedően teljesítettek az új évezred első évtizedében. Míg 2003-ban csak négy került be közülük a világ 500 (árbevétel alapján) legnagyobb vállalata közé, 2013-ban már nyolc szerepelt a listán (és 2019-ben is ugyanennyi, Id. Fortune, 2020). A legnagyobb és a nemzetközileg legaktívabb brazil cégek tekintetében egyet kell értenünk Casanova és Kassum $(2014,79$. o.) megállapításával: „a legnagyobb brazil vállalatok nem feltétlenül nagyon aktívak a nemzetközi piacokon, míg az ott legaktívabbak nem feltétlenül nagyon nagyok". Ugyanakkor Brazília kapcsán még így is a nagyvállalatok (még ha nem is a legnagyobbak) dominanciája figyelhető meg a nemzetközi piacokon, míg a kis- és közepes méretű vállalatok (kkv-k) alig jelennek meg külföldön. A következő alfejezetben bemutatjuk, hogy a brazil gazdaságpolitika is mindig főleg a nagyobb brazil cégek nemzetköziesedését támogatta, és nem találtunk olyan speciális eszközöket és intézkedéseket, amelyek kifejezetten a kkv-k nemzetközi (vagy akár hazai) tevékenységét ösztönözték volna.

A történeti áttekintés során bemutattuk, hogy a tágan értelmezett makrogazdasági trendek jelentősen befolyásolták a brazil vállalatok nemzetközi terjeszkedését. Az alábbiakban elsőként ezekre térünk ki, majd a vállalati szintű tényezők közös vonásait emeljük ki (bár azok értelemszerūen egyediek és esetenként vizsgálandóak).

A brazil kiáramló tőke felfutása mögött számos különböző (időben egybeeső) fejlemény állt. Először is, gazdasági téren a felfutó exportteljesítmény (elsősorban az elsődleges áruk kivitelének a gyors bővülése) jelentős kereskedelmi többletet eredményezett, s az a nagymennyiségú beáramló tőkével, valamint a valuta (reál) felértékelődésével együtt felduzzasztotta a devizatartalékokat, és mindez kedvezően hatott a brazil cégek külpiaci befektetési hajlandóságára. Elsősorban a hagyományosan

4 2015-ben és 2016-ban, vagyis két egymást követő évben több mint 3,5 százalékos visszaesés mutatkozott, ami a legsúlyosabb gazdasági válság Brazília modern története során. 
kompetitív előnyökkel rendelkező (vasérc, acél, szója, hús kivitelével foglalkozó) exportorientált cégek profitáltak a hazai pénzügyi piacon jelentkező kedvező finanszírozási feltételekből a jellemzően piackereső külföldi beruházásaik során (Campanario, Stal és Silva, 2012). Természetesen a globális piaci lehetőségek is kedveztek e cégeknek, hiszen a nyersanyagárak emelkedtek, a kínai kereslet gyorsan növekedett, így a világpiacon uralkodó optimista hangulat és az emelkedő befektetői bizalom egyaránt húzóerőként jelent meg. Mindezek alapján nem meglepő, hogy a szektorális eloszlásban a nyersanyagalapúak (fémek, bányászat, olaj- és gázkitermelés, acélgyártás) felfutása volt megfigyelhető (Resende, Almeida és Ramsey, 2010).

Második tényezőként említjük a kedvező (nemzetközi és hazai) gazdasági feltételek mellett a brazil gazdaságpolitika terén bekövetkezett alapvető változásokat (Casanova és Kassum, 2014, 68. o.). Ez a legjobban talán az akkori elnök, Lula szavaival illusztrálható, aki 2003-ban, a portugál ipari szövetség lisszaboni találkozóján arra ösztönözte a brazil cégeket, hogy lépjenek ki a nemzetközi piacra, és célként túzte ki, hogy 2010-re legalább tíz, valóban multinacionális vállalata legyen Brazíliának (UNCTAD, 2004).

Mindezek tükrében megállapítható, hogy az ezredfordulót követően a külföldi piacok irányába való terjeszkedés egyik fő hajtóereje a természeti erőforrásokhoz való hozzáférés biztositása volt, és ez értelemszerúen elsősorban a nyersanyagalapú vállalatok, például a Petrobras és a Vale esetében dominált. A második hajtóerő, amely leginkább az értéklánc magasabb szintjein lévő vállalatok esetében játszott fontos szerepet, az a szándék volt, hogy jobban tudjanak alkalmazkodni a helyi igényekhez, és azáltal, hogy könnyebben reagálnak az ottani sajátosságokra, előnyt élvezzenek e piacokon. Jó példa erre a repülőgépgyártó Embraer és az autóbuszgyártó Marcopolo vállalat: ők kereskedelmi irodákat nyitottak és leányvállalatokat hoztak létre annak érdekében, hogy közelebb legyenek az ügyfeleikhez. Harmadik hajtóerôként a brazil exportőrök azon szándékát említhetjük, hogy elkerüljék a vám- és nem vámjellegú kereskedelmi akadályokat, s ezért termelési egységeket múködtettek a felvevőpiacaikon (ahelyett, hogy kizárólag export révén látták volna el azokat). Példaként említhetjük erre a Gerdau acélipari vállalat és a Cutrale narancslégyártó cég terjeszkedését. Végül, de nem utolsósorban sok vállalat tanulási céllal döntött a nemzetközi terjeszkedés mellett, hogy így segítsék elő az értékláncon belüli feljebb lépést (upgrade), hiszen a világpiacon erősebb versenyhelyzetnek vannak kitéve, mint a meglehetősen védett és zárt hazain. Ez a stratégia fóleg a kiskereskedelmi ágazatra és az élelmiszeriparra jellemző, és a kozmetikai termékekkel foglalkozó Natura cég kiskereskedelmi üzletének Párizsban, a szépségipar nemzetközi központjában történt megnyitása a klasszikus példa rá (Casanova és Kassum, 2014, 85. o.).

A brazil vállalatok számos különleges, egyedi jellemzője (pl. az állami tulajdon vagy befolyás dominanciája, a családi vállalkozások nagy súlya, a hierarchikus piacgazdasági struktúra) közül gyakran kiemelik, hogy jó volatilitástưrő képességgel (resilience 
to volatility) rendelkeznek, azaz a hosszú évtizedek alatt megtanulták, hogyan lehet bizonytalan gazdasági körülmények között is múködni. Ezt a komparatív előnyt a 20. század második felében szerezték meg, amikor is ismétlődő válságok, szúk keresztmetszetú infrastruktúra és túlszabályozott piacok jellemezték a múködési környezetüket - az akkori brazil gazdaságot gyakran a világ egyik legnagyobb kihívást jelentő üzleti környezeteként írják le. Bár e feltételek annak idején napi szinten negatívan befolyásolhatták a vállalatok múködését és hosszú távú fejlesztési kilátásait, napjainkban az akkor megszerzett, visszás körülmények között is sikeres múködésre való képesség versenyelőnynek tekinthető, hiszen ma is számos hasonló korlátozással (fizikai vagy jogi infrastrukturális hiányosságokkal) szembesülhetnek. Jó példa erre az élelmiszer-feldolgozó BRF cég esete, amely világszínvonalú elosztóhálózatot fejlesztett ki a fagyasztott és hútött termékei számára, és sikerült a közel-keleti régió felé is terjeszkednie, miközben ott az arab piacokra jellemző összes hiányossággal szembesülni kényszerült (Casanova és Kassum, 2014, 85. o.).

A brazil multinacionális vállalatok nemzetközi terjeszkedését vizsgáló 2017-es felmérés (Sheng és Carrera, 2017) szerint a nemzetközi piacra lépés, illetve a külföldi befektetések legfontosabb hajtóerői fontossági sorrendben: új piacokhoz való hozzáférés; az ügyfelek közelsége; költségcsökkentés; a természeti erőforrásokhoz való hozzáférés; magas adók és intézményi visszásságok Brazíliában (például korrupció, rossz szállítási infrastruktúra és a szakképzett munkaerő hiánya). Egyes vállalatok az új technológiákhoz való hozzáférést is említették, de azt jellemzően hátrébb rangsorolták, mint a felsoroltakat. Külön ki kell emelni a brazil cégek külföldre lépésének fontos ösztönző tényezőjét, a magas adók és az intézményi visszásságok elkerülését, hiszen az egy olyan egyedi hajtóerő, amely kevésbé jelenik meg a szakirodalomban (azaz az elsősorban a fejlett országokat vizsgáló elemzésekben és elméletekben szereplő klasszikus FDItolóerők között).

\section{A brazil multinacionális vállalatok nemzetközi beruházásait támogató kormányzati politika}

A brazil cégek nemzetközi piacra lépésének főbb hajtóerői között számos olyan, speciálisan Brazíliára jellemző tényező sorolható fel, amely kiemelkedő szerepet játszott a vállalati struktúra kialakulása során. Ilyen a családi vállalkozások jelentôs túlsúlya (Perez és Lluch, 2016), az állami vállalatok dominanciája és az állam kiterjedt (közvetlen és közvetett) gazdasági szerepvállalása (Musacchio és Lazzarini, 2014), valamint a természeti erőforrásokkal való kedvező ellátottság és az importhelyettesítő iparosítás hagyatéka. Az ez utóbbi keretében megvalósított, a "nemzeti bajnokokat" támogató gazdaságpolitika jelentősen hozzájárult ahhoz, hogy a brazil piacgazdaság hierarchikus struktúrája kialakuljon és napjainkig fennmaradjon (Schneider, 2013). Az 1990-es 


\section{Külügyi Szemle}

liberalizációt és privatizációt követően számos korábbi nemzeti bajnok megtartotta, sőt javította a hazai és a nemzetközi piacokon elért vezető pozícióját. E tekintetben a leggyakrabban emlegetett példa az Embraer, a Vale és a Petrobras.

A külföldi beruházások közvetlen támogatása a 2000-es évekig nem jelent meg egyértelmúen a gazdaság- és fejlesztéspolitikai célkitúzések között. A nemzetköziesedés korai időszakában a brazil vállalatok nemzetközivé válása egy szerves, nagyrészt saját maguk által vezérelt folyamat volt (Fleury és Fleury, 2011), az államnak akkoriban nem volt kulcsfontosságú (közvetlen) szerepe. A 2000-es évek elejétől a Brazil Fejlesztési Bank (BNDES) által nyújtott támogatásnak új formái jelentek meg; eleinte azonban azok önálló programok maradtak, és nem létezett átfogó stratégia a vállalatok globális terjeszkedésének elősegítésére.

Ugyanakkor az első közvetlen intézkedés mégis 1998-ra nyúlik vissza: a BNDES akkori speciális hitelkerete azt célozta, hogy a külföldi kormányzatok a nagy (latin-amerikai és afrikai) infrastrukturális projektjeik megvalósítása során kedvezőbb feltételekkel alkalmazzanak brazil vállalatokat (és így azok versenyképesek legyenek a kínaiakkal szemben, amelyek már akkoriban is erős kormányzati hátszéllel terjeszkedtek). A BNDES nyújtotta hitelek az építési projektek összértékének akár a 85 százalékát fedezték, így azok nemcsak elérhetővé, de vonzóvá is váltak a brazil multinacionális nagyvállalatok számára. További előfeltétel volt, hogy minden külföldi infrastrukturális projekt esetén a Brazíliában gyártott termékeknek a bank által folyósított összeg legalább 35 százalékát kellett kitenniük. E követelményt a hazai termelés támogatása és a brazil ellátási láncok fejlesztése érdekében támasztották a cégek elé. Az első öt évben a BNDES azonban mindössze öt projektet finanszírozott (mindegyik Dél-Amerikában valósult meg), és a támogatás átlagos értéke 74 millió dollárt tett ki (Caseiro-Masiero, 2014, 241-242. o.).

A brazil vállalatok külföldi befektetéseinek közvetlen finanszírozását szolgáló második eszközt 2002-ben vezették be, és az már nem csupán hitellehetőség volt, hanem értékpapírok jegyzését is magában foglalta. Első ízben 2005-ben vették igénybe, amikor a JBS megvásárolta az amerikai versenytársa, a Swift társaság argentin leányvállalatát. Kiegészítő intézkedésként a Brazil Központi Bank (BCB) törölte az addig minden 5 millió dollár feletti OFDI-projektre érvényes előzetes engedélyeztetési követelményt, amit fontos mérföldkőnek kell tekinteni a brazil OFDI-politikában. Összességében kijelenthető, hogy 2007-ig inkább egyedi intézkedéseket léptettek életbe az OFDI támogatására (gyakorlatilag két hitelkeretet és az előzetes engedélyeztetés eltörlését), de azok nem álltak össze koherens politikai csomaggá.

2007 azonban fontos fordulópontot jelentett a brazil OFDI-t ösztönző politika tekintetében, mivel abban az évben fogadták el az új iparpolitikai dokumentumot (Política de Desenvolvimento Produtivo, PDP), amely egyértelmú célokat túzött ki az OFDI támogatása érdekében, és egy koherensebb politikai megközelítést jelentett. A PDP stratégiai céljai között szerepelt a feltörekvő brazil multinacionális vállalatok nemzetközi vezető 
szerepének bővítése és megszilárdítása azokban a stratégiai iparágakban, amelyekben az ország már korábban is nemzetközileg versenyképes volt, például a repülőgépgyártás, az olaj- és gázipar, a vegyészet (petrolkémiai szektor), az etanolgyártás, a bányászat, az acélipar, a cellulóz- és papír-, illetve a húsipar terén (Ministério do Desenvolvimento, Indústria e Comércio Exterior, 2008).

2005 és 2011 között a BNDES összesen 4,9 milliárd dollárral támogatta a brazil vállalatok nemzetközivé válását - szinte kizárólag értékpapírjegyzés (részvényvásárlás) révén -, valamint továbbra is finanszírozza a tengerentúli infrastrukturális projekteket. Ez utóbbiak éves átlagos összege az 1998 és 2002 közötti 350 millióról 2007 és 2012 között 1,1 milliárd dollárra, a számuk pedig ötről kilencvenhétre nőtt (Caseiro és Masiero, 2014, 242. o.). Bár a technológiaintenzív cégek nemzetközi terjeszkedésének támogatása szintén megjelent a fejlesztéspolitikai célok között, az azonban korlátozott maradt, és a BNDES által finanszírozott OFDI-projektek túlnyomó többsége (több mint 95\%-a) húsfeldolgozó vállalatokhoz (pl. JBS és Mafrig) kapcsolódott.

De nem csak az OFDI-projektek közvetlen finanszírozása segítette a vállalatok nemzetköziesedését. A brazil fejlesztési bank számos hazai akvizíciót (felvásárlást) is támogatott, ami az adott cégek számára a brazíliai piacon az iparágon belüli pozíciójuk megerősítését eredményezte (elsősorban a "nemzeti bajnokok" számára), egyúttal viszont a kis- és középvállalkozásokat hátrányos helyzetbe hozta.

A régi-új brazil iparpolitikát számos kritika érte, és a helyi üzleti elit bizonyos köreinek a nyomása is erősödött, de csak az elnöki poszton bekövetkezett váltás eredményezte a 2011-es új iparpolitikai dokumentum megszületését, amely a Brasil Maior nevet kapta. Az új prioritásoknak megfelelően ebben erősebb hangsúlyt kapott azon cégek nemzetköziesedésének a támogatása, amelyek új technológiákhoz vagy piacokhoz való hozzáférés érdekében terveztek külföldi befektetéseket. Ugyanakkor semmilyen konkrét eszközt vagy intézkedést nem rendeltek hozzá ehhez az újrafogalmazott prioritáshoz, így - nem meglepő módon - nem is történt érdemi változás.

Annak ellenére, hogy 2007 és 2011 között Brazíliában viszonylag koherens szakpolitikai keret létezett a brazil vállalatok nemzetközivé válásának előmozdítása érdekében, számos tényező akadályozta a megvalósítást. Egyrészt az ország nem léptette életbe a kétoldalú beruházási szerződéseit, ${ }^{5}$ amelyek pedig csökkenthették volna a külföldi befektetések politikai kockázatát (ez főként a brazil kongresszus ideológiai ellenállásának a következménye volt, amely az 1990-es években és a 2000-es évek elején megvétózta e megállapodásokat, de a ratifikációjukat még a közelmúltban is jellemzően ellenezte, azzal az érveléssel, hogy azok az ország szuverenitását fenyegetik). Másrészt annak ellenére, hogy Brazília huszonkilenc országgal írt alá szerződést

5 Brazília összesen húsz kétoldalú beruházási szerződést kötött, közülük hetet 2015-ben (Angola, Chile, Kolumbia, Malawi, Mexikó, Mozambik és Peru), és egyet 2016-ban kezdeményezett, Indiával (UNCTAD. Investment Policy Hub, 2020). 
a (multinacionális vállalatokra és helyi leányvállalataikra vonatkozó) kettős adóztatás elkerülése érdekében, azok egyike sem a brazil cégek fóbb partnerországával (például az USA, Németország vagy az Egyesült Királyság) köttetett. Ezt talán a pénzügyminisztérium heves ellenállása magyarázhatja, amely attól félt, hogy jelentős adóbevételtól esne el - ez viszont oda vezetett, hogy a brazil OFDI célországai között aránytalanul nagy súlyt képviselnek az ún. adóparadicsomok.

\section{Következtetések: \\ a kínai és a brazil tőkekihelyezési stratégiák összehasonlítása}

A kínai és a brazil példa is jól mutatja, hogy az FMNV-k globális terjeszkedése új és dinamikus folyamat, amelyben a lökést adó (push) tényezők sok szempontból eltérnek a fejlett országok multinacionális vállalatainak "klasszikus" hajtóerőitől. Bár a strukturális, illetve makrogazdasági tényezők szerepe nem elhanyagolható motiváció az előbbiek esetében sem, de a befektetéseikben az intézményi tényezők - azon belül is a kormányzati politika - kiemelkedóen fontos szerepet játszanak.

A jelen írás a hazai kormányzatnak a vállalati tőkekihelyezések intézményi tényezőjeként betöltött szerepét vizsgálta. A kínai és a brazil állam által irányított OFDI-stratégiák elemzése alapján jól láthatóvá vált, hogy mindkét kormány egyszerre alkalmazott proaktív és intervenciós stratégiákat a hazai vállalatok nemzetközi terjeszkedésének elősegítése érdekében. Tanulmányunk során arra a megállapításra jutottunk, hogy e vonás - azaz az államnak a vállalati tôkekihelyezésekre vonatkozó kezdeményezése és az azokba való beavatkozása - alapvetően megkülönbözteti az FMNV-ket a fejlett országok multinacionális vállalataitól. A kínai és a brazil tókekihelyezési stratégiák öszszehasonlításával azonban rávilágíthatunk a közöttük levő különbségekre, amelyekből gazdaságpolitikai értelemben is releváns következtetéseket vonhatunk le. E következtetések (reményeink szerint) hasznos tanulságul szolgálhatnak más feltörekvő gazdaságok számára is.

A kínai vállalatok kisebb-nagyobb korlátozásokkal már az 1980-as, 1990-es években megkezdték a külföldi tőkekihelyezést, de a valódi lökést az új évezred kezdetének állami/kormányzati elhatározása (és az annak érdekében kialakított ösztönzői) jelentették. A go global politika meghirdetése, illetve annak részeként a WTO-csatlakozás, akárcsak a kínai vállalatok beruházásai, Peking globális szerepének a megalapozását célozták. Felismerték ugyanis, hogy a cégei megjelenése révén az ország nem csupán gazdasági haszonra tesz szert, hanem azok imázsán keresztül Kína megítélése is javulhat. Ennek érdekében komplex, az egész gazdaságot átfogó programok születtek, s a legkülönbözőbb szektorokban jelentek meg a kínai nemzeti bajnok vállalatok, amelyek közül több nem is állami, hanem magántulajdonú. 
Kínától eltérően, Brazíliában viszonylag későn, csak a Munkáspárt (Partido dos Trabalhadores, PT) 2003-as hatalomra kerülése után kerültek újra napirendre az aktív iparpolitikai beavatkozások. Ennek keretében nemcsak az állami szerepvállalás korábbi (közvetlen és közvetett) csatornáit (például az arany részesedését, a nyugdíjalapokon és a nemzeti fejlesztési bankon keresztül történő kereszttulajdonlásokat) tartották fenn és erősítették meg, hanem új hitelkonstrukciókat is bevezettek a nemzeti bajnokoknak a nemzetközi piacokon való sikeres fellépésének a támogatására. Azok azonban önálló programok maradtak, és nem jött létre a vállalatok globális terjeszkedését elősegító átfogó stratégia. Ez élesen eltér a kínai és néhány más ázsiai ország (például Dél-Korea) gyakorlatától, ahol a fejlesztésorientált kormányzatok voltak a vállalatok nemzetközivé válásának a legfőbb hajtóerői, hiszen aktívan támogatták a stratégiai iparágak globális versenyképességét. A brazil (ugyancsak fejlesztésorientált) kormányzatokat azonban befelé forduló, defenzív iparosítás jellemezte, amely a nemzetközi verseny kizárásán alapult. Napjainkra nyilvánvalóvá vált, hogy Brazíliában a külföldi közvetlen tőkebefektetéseket gyakran ellentmondásos (és vitatott) állami politikákon keresztül támogatták, és azok visszásságaira egyrészt a közelmúlt korrupciós botrányai, másrészt a gazdasági teljesítmény tekintetében is látható, kedvezőtlen hosszabb távú tendenciák világítottak rá.

A kínai állam a vállalatok globális versenyképességének elősegítése érdekében olyan új rendelkezéseket, politikákat vezetett be, amelyek arra ösztönözték/ösztönzik őket, hogy egyre több régióban és iparágban jelenjenek meg a befektetéseikkel. A kormányzati politika ugyanakkor nem csupán bátorítja, támogatja a tókekihelyezést, de sok esetben arra is befolyással bír, milyen országokat, illetve szektorokat célozzanak a vállalatok. Előnyt élveznek például a Kína-barát országok piacai, a fontosabb gazdasági régiók vagy a főbb kereskedelmi partnerek. Az ajánlottak közé bekerült államok valóban szignifıkánsan több kínai közvetlentőke-befektetést fogadnak, mint a listán nem szereplők, de a preferált szektorok esetében is megfigyelhető, hogy a kínai vállalatok valóban az állami direktíva mentén cselekszenek. A kínai OFDI-politika tehát jól végiggondolt, az egész gazdaság szempontjait szem előtt tartó stratégia eredményeként született, meglehetősen offenzív stílusú, de minden kétséget kizáróan sikeres, hiszen Kína ma már a legjelentősebb tőkekihelyező országok egyike.

A Brazília "globális felemelkedését" célzó OFDI-politika viszont összességében egy „védekező típusú" (defenzív) iparpolitikai stratégia része volt. Az BNDES-nek az OFDI-t támogató finanszírozása többnyire olyan ágazatokba áramlott, amelyek az importhelyettesítő iparosítás (IHI) időszakában kialakult brazil ipari komplexumot (magot) alkották (elsősorban a húsfeldolgozás, az építőipar és a petrolkémia ágazatai). A 2007 és 2011 közötti támogatási hitelek zöme olyan nagyvállalatokhoz került, amelyek a nemzetközi pénzügyi piacokon is kölcsönhöz jutottak volna (Musacchio és Lazzarini, 2014), hiszen jellemzően a brazil gazdaság legversenyképesebb szereplői voltak. Ugyanakkor a kkv-k mint potenciális jövőbeli globális szereplők támogatása, illetve az olyan célok, 


\section{Külügyi Szemle}

mint a fogadó piacok dinamikus komparatív előnyeinek a kihasználása és/vagy a hazai piacokon tapasztalható szúk keresztmetszetek enyhítése, a brazil OFDI-stratégia fókuszán kívül maradtak.

Összességében tehát a brazil OFDI-stratégia sokkal inkább védekező volt, míg kínai versenytársát agresszívabb, támadóbb fellépés jellemezte. Brazília beruházásösztönző stratégiája kevésbé képes arra, hogy pozitív tovagyưrúző hatásokat fejtsen ki a hazai gazdaságra, így annak fejlesztésére is előnytelenebb, mint a kínai. Mindezek következtében a külföldön elért viszonylagos sikerek ellenére a brazil OFDI-politikák és tágabban véve az iparpolitikák (nem minden alap nélkül) napjainkban is a politikai és az akadémiai viták középpontjában állnak.

Nemzetközi összehasonlításban az OFDI-t ösztönző brazil politika valahol félúton helyezkedik el: más feltörekvő országokénál (pl. Kína) sokkal kevésbé intervencionista, és inkább védekező stratégia jellemzi, míg a fejlett országokénál vagy a nála liberálisabb elveket követő regionális versenytársakénál (pl. Chile) sokkal inkább államilag vezérelt és irányított. A brazil kormány közvetlen befolyást (többségi tulajdona révén) csak a két állami nagyvállalat (a Petrobras és a Banco do Brasil) esetében gyakorol, míg a többiben „csak" kisebbségi részvényes. Ugyanakkor például a csaknem kizárólag a BNDES-en keresztül nyújtott hosszú távú (támogatási) hitelek révén az államnak a brazil gazdaságra való befolyása lényegesen nagyobb, jóllehet az többnyire közvetett csatornákon keresztül érvényesül.

A kínai és a brazil OFDI-stratégiák összehasonlítása révén összességében arra a következtetésre juthatunk, hogy a pekingi kormányzaté sokkal agresszívabb volt a kínai vállalatok külföldi terjeszkedése tekintetében, míg a brazil inkább védekezőnek tekinthető. A brazil iparpolitika a már meglévő dinamikus komparatív előnyökre összpontosított: inkább azon iparágakat támogatta, amelyek nemzetközileg már versenyképesek voltak, és nem járultak hozzá a hazai gazdaság strukturális átalakulásához. A kínai kormány ellenben az ottani vállalatok külföldi terjeszkedését elsősorban annak érdekében támogatta, hogy az ország számára szükséges természeti erőforrásokhoz való hozzáférést biztosítsa, de bőven akadt példa a piac- és hatékonyságkereső motivációkra is, és - kifejezetten az utóbbi időkben - fontos tolóerőt jelentett az új technológiák és a vezetői tapasztalatok megszerzése is. Különösen hangsúlyozandó, hogy a kínai kormány ezáltal úgy segítette és irányította az OFDI-t, hogy közben a hazai gazdaság fejlődését, sőt a strukturális átalakulását is szem előtt tartotta. E célból elsősorban a fogadó országokban elérhető dinamikus komparatív előnyökre összpontosított. Tőle eltérően, a brazil kormány sokkal inkább a meglévő komparatív előnyeire támaszkodott (ahelyett, hogy újak létrehozását célozta volna meg), és a hagyományosan vezető pozícióban lévő vállalatok nemzetközi terjeszkedését támogatta (amelyek valószínúleg állami beavatkozás nélkül is sikeresek lehettek volna). 
A további lehetséges kutatási irányok közül kiemelkedik az orosz, az indiai és a dél-afrikai esetek bevonása az elemzésbe. Az ezen országok bármelyike - vagy egy nagyobb összehasonlítás keretében akár mindegyike - vonatkozásában teendő megállapítások megfelelően árnyalhatnák az autoriter, erősen centralizált, központi stratégiával rendelkező (és gazdaságilag is jól teljesítő) kínai, illetve a demokratikus, gyengébb központi kormányzati befolyással bíró (és gazdaságilag is hullámzó teljesítményû) brazil példa összevetése alapján megfogalmazott következtetéseket.

\section{Irodalomjegyzék}

Abreu Campanario, Milton de, Stal, Eva és Muniz da Silva, Marcello (2012). Outward FDI from Brazil and Its Policy Context, from Inward and Outward FDI Country Profiles. New York, NY: Vale Columbia Center on Sustainable International Investment.

Casanova, Lourdes és Kassum, Julian (2014). The Political Economy of an Emerging Global Power. In Search of the Brazil Dream. Basingstoke: Palgrave Macmillan.

Caseiro, Luiz Carlos Zalaf és Masiero, Gilmar (2014). OFDI Promotion Policies in Emerging Economies: The Brazilian and Chinese Strategies. Critical Perspectives on International Business, 10(4), 237-255.

Clegg, Jeremy és Voss, Hinrich (2012). Chinese Overseas Direct Investment in the European Union. ECRAN. A letöltés ideje: 2021. január 5. https://www.chathamhouse. org/sites/default/files/public/Research/Asia/0912ecran_cleggvoss.pdf.

Davies, Ken (2013). China Investment Policy: An Update. OECD iLibrary. A letöltés ideje: 2017. augusztus 17. https://www.oecd-ilibrary.org/finance-and-investment/chinainvestment-policy_5k469l1hmvbt-en.

Fleury, Afonso és Fleury, Maria Tereza (2011). Brazilian Multinationals: Competences for Internationalization. Cambridge: Cambridge University Press.

Fortune (2020). Global 500. A letöltés ideje: 2020. szeptember 8. http://fortune.com/ global500/.

Hanemann, Thilo és Huotari, Mikko (2017). Record Flows and Growing Imbalances: Chinese Investment in Europe in 2016. MERICS. A letöltés ideje: 2017. október 15. https://merics.org/en/report/record-flows-and-growing-imbalances-chineseinvestment-europe-2016.

Kurlantzick, Joshua (2016). State Capitalism. How the Return of Statism is Transforming the World. New York, NY: Oxford University Press.

Luo, Yadong, Xue, Qiuzhi és Han, Binjie (2010). How Emerging Market Governments Promote Outward FDI: Experience from China. Journal of World Business, 45(1), 68-79.

Ministério do Desenvolvimento, Indústria e Comércio Exterior (2008). Política de desenvolvimento produtivo, 2008. A letöltés ideje: 2017. július 3. www.mdic.gov.br.

Ministry of Commerce People's Republic of China (2004). Foreign Trade Law of the People's Republic of China. A letöltés ideje: 2021. január 5. http://english.mofcom.gov. cn/aarticle/policyrelease/internationalpolicy/200705/20070504715845.html.

Morrison, Wayne M. (2013). China's Economic Conditions. Congressional Research Service. A letöltés ideje: 2017. augusztus 15. https://www.refworld.org/ pdfid/514188cd2.pdf. 


\section{Külügyi Szemle}

Musacchio, Aldo és Lazzarini, Sergio G. (2014). Reinventing State Capitalism. Leviathan in Business, Brazil and Beyond. Cambridge, MA: Harvard University Press.

Naughton, Barry J. (2007). The Chinese Economy: Transitions and Growth. Cambridge, MA: MIT Press.

Nölke, Andreas (2014). Private Chinese Multinationals and the Long Shadow of the State. In Andreas Nölke (szerk.), Multinational Corporations from Emerging Markets. State Capitalism 3.0 (77-89. o.).

Nölke, Andreas, Ten Brink, Tobias, Claar, Simone és May, Christian (2015). Domestic Structures, Foreign Economic Policies and Global Economic Order: Implications from the Rise of Large Emerging Economies. European Journal of International Relations. 27(3), 538-567.

Perez, Paloma Fernandez és Lluch, Andrea (2016). Evolution of Family Business. Continuity and Change in Latin America and Spain. Cheltenham: Edward Elgar.

Resende, Paulo, Almeida, André és Ramsey, Jase (2010). The Transnationalization of Brazilian Companies: Lessons from the Top Twenty Multinational Enterprises. In Karl P. Sauvant, Geraldine McAllister és Wolfgang A. Maschek (szerk.), Foreign Direct Investments from Emerging Markets: The Challenges Ahead (97-111 o.).

Ricz Judit és Nagy Sándor Gyula (2016). A brazil gazdasági válság: helyzetkép, okok és kiutak. Külügyi Szemle, 15(3), 94-120.

Ricz Judit és Szunomár Ágnes (2020). Államvezérelt globális vállalati terjeszkedés: a kínai offenzív versus a brazil defenzív stratégia. Köz-Gazdaság, 15(1), 159-171.

Rosen, Daniel H. és Hanemann, Thilo (2013). China's Direct Investment in Advanced Economies: The Cases of Europe and the United States. China Economist, 8(5), 65-79. Sauvant, Karl P. és Chen, Victor Zitian (2014). China's Regulatory Framework for Outward Foreign Direct Investment. China Economic Journal, 7(1), 141-163.

Sauvant, Karl P., Economu, Persephone, Gal, Ksenia, Lim, Shawn és Wilinski, Witold P. (2014). Trends in FDI, Home Country Measures and Competitive Neutrality. In Andrea K. Bjorklund (szerk.), Yearbook on International Investment Law and Policy 2012-2013 (3-107. 0.).

Schneider, Ben Ross (2013). Hierarchical Capitalism in Latin America. Business, Labor, and the Challenges of Equitable Development. Cambridge: Cambridge University Press.

Schüler-Zhou, Yun, Schüller, Margot és Brod, Magnus (2012). Push and Pull Factors for Chinese Outward FDI in Europe. In Ilan Alon, Marc Fetscherin és Philippe Gugler (szerk.), Chinese International Investments (157-174. o.).

Scissors, Derek (2014). China's Economic Reform Plan Will Probably Fail. American Enterprise Institute. A letöltés ideje: 2017. augusztus 15. https://www.aei.org/wpcontent/uploads/2014/02/-chinas-economic-reform_130747310260.pdf.

Sheng, Hsia Hua és Carrera, José Marcos Junior (2017). The Top 20 Brazilian Multinationals: Divestment Under Crises. São Paulo és New York, NY: Fundação Getulio Vargas és Columbia Center on Sustainable Investment.

Ten Brink, Tobias (2013). Chinas Kapitalismus. Entstehung, Verlauf, Paradoxien. Frankfurt am Main: Campus Verlag.

UNCTAD (2004). Outward FDI from Brazil: Poised to Take off? A letöltés ideje: 2017. július 6. http://unctad.org/en/docs/iteilia200416_en.pdf. 
UNCTAD (2013). World Investment Report 213. Global Value Chains: Investment and Trade for Development. Genf: United Nations.

UNCTAD. Investment Policy Hub (2020). International Investment Agreements Navigator. A letöltés ideje: 2021. január 21. https://investmentpolicy.unctad.org/internationalinvestment-agreements.

Voss, Hinrich, Buckley, Peter J. és Cross, Adam R. (2009). An Assessment of the Effects of Institutional Change on Chinese Outward Direct Investment Activity. In Ilan Alon, Julian Chang, Marc Fetscherin, Christoph Lattemann és John R. Mclntyre (szerk.), China Rules - Globalization and Political Transformation (135-165. o.).

Wang, Bijun (2013). A Misread Official Data: The True Pattern of Chinese ODI. International Economic Review (GuoJi Jing Ji Ping Lun), (1), 61-74.

Witt, Michael A. és Redding, Gordon (2013). Asian Business Systems: Institutional Comparison, Clusters and Implications for Varieties of Capitalism and Business Systems Theory. Socio-Economic Review, 11(2), 265-300. 